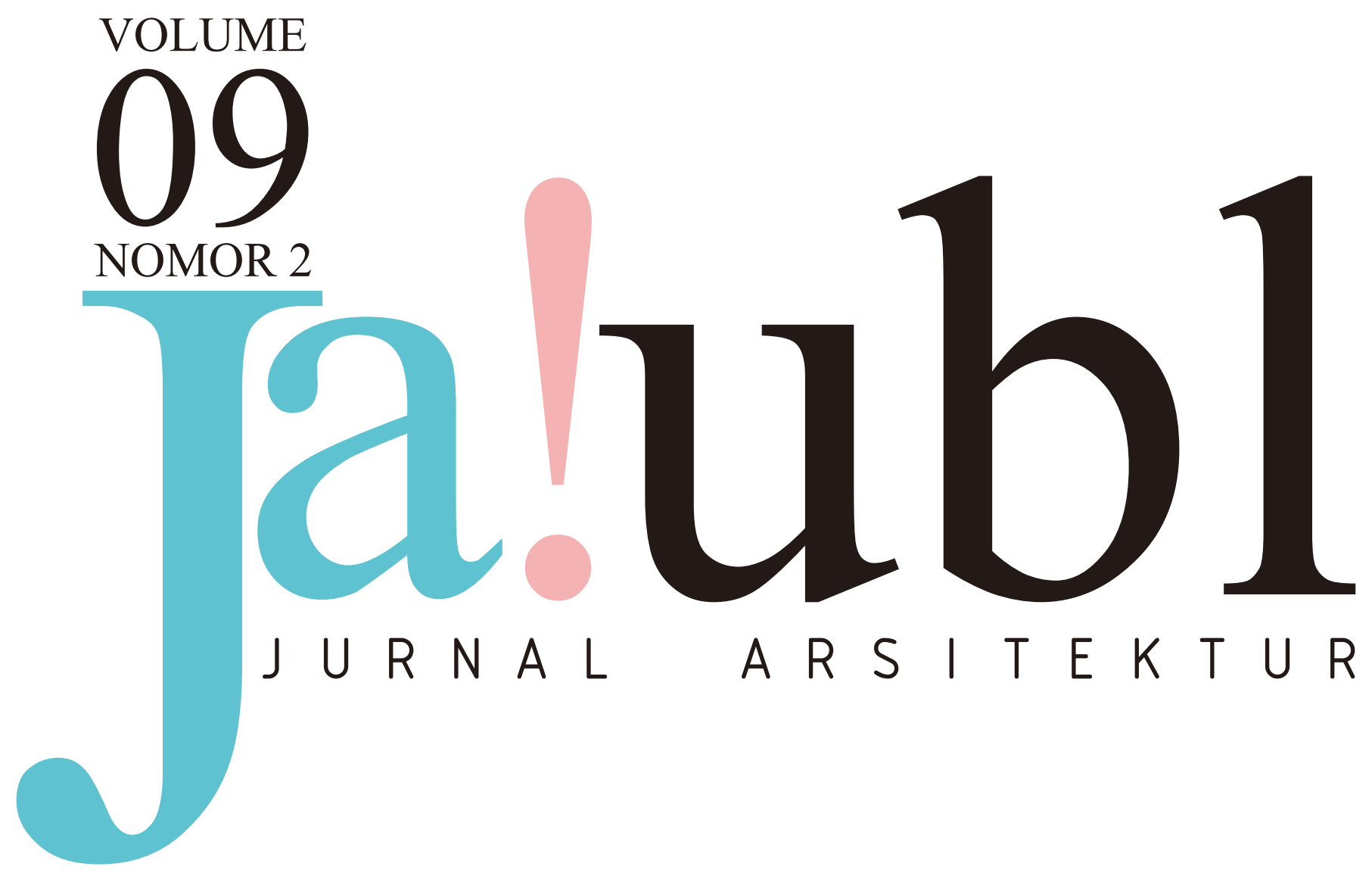


JA!UBL - Jurnal Arsitektur

Terbit dua kali setahun pada bulan Januari dan Juli. Diterbitkan oleh Program Studi Arsitektur Fakultas Teknik Universitas Bandar Lampung. JA!UBL merupakan media pendokumentasian, sharing, dan publikasi karya ilmiah yang berisi karya-karya riset ilmiah mengenai bidang ilmu perancangan arsitektur dan bidang ilmu lain yang sangat erat kaitannya seperti perencanaan kota dan daerah, desain interior, perancangan lansekap, dan sebagainya.

ISSN: 2087-2739

\section{PELINDUNG}

Dr. Ir.H.M.Yusuf Barusman, M.B.A. (Universitas Bandar Lampung)

\section{PENASEHAT}

Dr. Ir. Hery Riyanto, M.T. (Universitas Bandar Lampung)

PENANGGUNG JAWAB

Ir. Tjetjeng Sofjan S., M.M., M.T. (Universitas Bandar Lampung)

\section{PIMPINAN REDAKSI}

Dr.Eng. Haris Murwadi, S.T., M.T.

\section{REDAKSI PELAKSANA}

Shofia Islamia Ishar, S.T., M.T.

Dadang Hartabela, S.T., M.T.

Ai Siti Munawaroh, S.Pd., M.I.L.

Indyah Kumoro Wardani, S.T., IAI

\section{DEWAN REDAKSI}

Prof. Dr. Julaihi Wahid (Universitas Sains Malaysia)

Prof. Dr. Ir. H. Slamet Tri Sutomo, M.S (Universitas Hasanuddin)

Prof. Ir. Totok Rusmanto, M.Eng. (Universitas Diponegoro)

Prof. Dr. Ing. Ir Gagoek Hardiman. (Universitas Diponegoro)

Dr.Eng. Fritz Akhmad Nuzir, S.T., M.A.(L.A.) (Universitas Bandar Lampung)

David Hutama, ST., M.Eng (Universitas Pelita Harapan)

\section{MITRA BESTARI}

Dr. Ir. Budi Prayitno, M.Eng. (Universitas Gajah Mada)

Dr. Eng. Ir. Ahmad Sarwadi, M.Eng (Universitas Gajah Mada)

Prof. Dr. T. Yoyok Wahyu Subroto, M.Eng. Ph. D. (Universitas Gajah Mada)

Dr.Eng. Fritz Akhmad Nuzir, S.T., M.A. (L.A.) (Universitas Bandar Lampung)

Prof. Ir. Liliany Sigit Arifin, M.Sc., Ph. D (Universitas Petra)

Dr. Budi Faisal (Institut Teknologi Bandung)

Dr.Eng. Agus Hariyadi, S.T., M.Sc. (Universitas Gajah Mada)

\section{TIM GRAFIS DESAIN}

Satrio Agung Perwira

B. Chrysvania Artemisia

\section{ALAMAT REDAKSI}

Program Studi Arsitektur Fakultas Teknik Universitas Bandar Lampung

Jalan Zainal Abidin Pagar Alam Nomor. 26 Labuhanratu, Bandarlampung, 35142

Telp. $\quad:$ :0721-773847

E-mail : : editor.j@ubl.ac.id

Homepage : ubl.ac.id 


\section{Daftar Isi Artikel}

01-06 Analisis Penerapan Art Deco pada Rumah di Bandung Periode Perang Dunia I-II Studi Kasus: Tiga Villa dan Perumahan Dosen UPI FADILASARI, Dewi

07-12 Tipologi Bentuk Atap pada Arsitektur Jawa ROOSANDRIANTINI, Josephine; SANTOSO, Angelina Novemita; AMBARWATI, Catherina Novita

13-18 Identifikasi Respon Pengunjung mengenai Keberadaan Desa Wisata Taman Purbakala Pugungraharjo Lampung HARTABELA, Dadang; MASITO, Yuni

19-26 Fenomena Terbentuknya Ruang Spatio-Temporal di Kawasan Stadion Pahoman Bandarlampung WIBAWA, M. Shubhi Yuda

27-32 Identifikasi Area Berpotensi Macet di Kawasan Pendidikan Jl. Z.A. Pagar Alam Bandarlampung PERWIRA, Satrio Agung; MURWADI, Haris; MUNAWAROH, Ai Siti; ISHAR, Shofia Islamia

33-40 Manfaat Ruang Terbuka dan Hubungannya dengan Kegiatan Interaksi Sosial Studi Kasus: Perumahan Nusa Tamalanrea Indah Makassar NURHIJRAH; WIKANTARIA, Ria 


\title{
Tipologi Bentuk Atap pada Arsitektur Jawa
}

\author{
Josephine Roosandriantini $^{1^{*}}$, Angelina Novemita Santoso ${ }^{2}$, Catherina Novita Ambarwati ${ }^{3}$ \\ 1) Dosen S1 Arsitektur, Fakultas Teknik, Unika Darma Cendika Surabaya \\ ${ }^{2)}$ Mahasiswa Arsitektur, Fakultas Teknik, Unika Darma Cendika Surabaya \\ ${ }^{3)}$ Mahasiswa Arsitektur, Fakultas Teknik, Unika Darma Cendika Surabaya \\ *Penulis Korespondensi: arch_book2010@yahoo.com; +628113444734
}

\begin{abstract}
In the beginning, the first creation of Javanese Architecture is the house of Javanese people. Those people are likes to turn their self-orientation and their way of life into symbols. Javanese Architecture is full of those symbols, so it can be said that the building itself is the mirror of the user. Arsitektur Nusantara's typology is divided into the shape of roof and the place-arrangement pattern. Between of those two aspects, the easiest way to identify is from the shape of roof. In this research is only covering about Joglo, Limasan, and Kampung shape of roof. This research used the descriptive method. Datas that already have been gathered, explained in descriptive way, and made into a summary from all those data. In conclusion, Shape of Roof in Javanese Architecture are influenced by the social state and economic state of the user.
\end{abstract}

Keywords : Javanese architecture; shape of roof; typology

\begin{abstract}
Abstrak
Bentuk awal hasil karya Arsitektur Jawa adalah tempat tinggal masyarakat Jawa. Manusia Jawa sangat memperhatikan orientasi diri dan refleksi sikap hidup mereka dan memasukkannya ke dalam berbagai simbol. Simbol-simbol ini kemudian diaplikasikan ke dalam Arsitektur Jawa, sehingga dapat dikatakan bahwa Arsitektur Jawa mencerminkan kedudukan pemiliknya. Tipologi arsitektur nusantara sendiri terbagi atas karakter atap dan pembagian ruang. Diantara kedua aspek tipologi tersebut, wujud fisik Arsitektur Jawa yang paling mudah diidentifikasi adalah bentuk atap. Bentuk atap rumah Arsitektur Jawa yang dibahas dalam penelitian ini adalah atap rumah bentuk Joglo, Limasan, dan Kampung. Penelitian ini memakai metode deskriptif. Data yang diambil dari buku maupun internet dikumpulkan, dijabarkan secara deskrptif, dan kesimpulan diambil dari data yang ada. Berdasarkan data yang telah dikumpulkan, dapat disimpulkan bahwa faktor-faktor yang mempengaruhi bentuk atap suatu arsitektur Jawa adalah kedudukan sosial pemilik dan kedudukan ekonomi pemilik.
\end{abstract}

Kata Kunci : arsitektur Jawa; bentuk atap; tipologi

\section{Latar Belakang}

Pada mulanya omah yang merupakan tempat tinggal masyarakat Jawa, merupakan bentuk fisik dari karya arsitektur Jawa itu sendiri. Kata omah merupakan peleburan dari dua kata, yaitu om yang diartikan sebagai angkasa dan bersifat laki-laki, dan lemah yang diartikan (tanah) dan bersifat perempuan. Perwujudan bentuk fisik ini terdiri atas dimensi guna dan citra.

Mangunwijaya (1992) mengatakan bahwa dimensi citra muncul dari upaya manusia sebagai makhluk yang berbudaya, sehingga dapat dikatakan bahwa arsitektur merupakan cermin dari suatu kebudayaan. Begitu juga dengan masyarakat Jawa yang mengekspresikan orientasi diri dan refleksi sikap hidup mereka ke dalam berbagai simbol, lalu mengaplikasikannya pada arsitektur Jawa.

Menurut Pitana (2007), simbol yang dipakai terdiri atas simbol materi dan simbol perilaku. Simbol materi ditujukkan untuk hal-hal yang bersifat fisik dan dapat ditangkap dengan kelima indra manusia, seperti tata massa bangunan, pola tata ruang, pola perwujudan bentuk bangunan, penggunaan material bangunan, dan desain ornamen bangunan. Sedangkan simbol perilaku ditujukkan untuk hal-hal yang berkaitan tindakan manusia dengan pembangunan rumahnya, seperti ritual, laku batin, dan gugon tuhon yang menyertai proses pembangunan rumah.

Bentuk atap bangunan tradisional Jawa mengambil filosofi bentuk dari gunung. Pada mulanya filosofi gunung ini diwujudkan ke dalam bentuk atap, yang kemudian dikenal sebagai atap Tajug. Seiring berjalannya waktu, bentuk atap tajug mengalami perubahan menjadi atap joglo, limasan, dan kampung (Prijotomo, 1995; Ismunandar, 1986). 
Menurut Hamzuri (1985), tipologi arsitektur Jawa diklasifikasikan terutama dalam karakter atap dan pembagian ruang, bentuk bangunannya terbagi dalam susunan mulai dari tingkatan yang tertinggi yaitu tajug (masjid), joglo (golongan nigrat), limasan (golongan menengah), Kampung (rakyat biasa) dan panggang pe (rakyat biasa). Rumah-rumah tersebut memiliki jenis atap yang berbeda untuk menunjukan kedudukan sosial dan ekonomi pemilik rumah. Sehingga bentuk atap merupakan bagian fisik dari arsitektur Jawa yang paling mudah diidentifikasi untuk menentukan bagaimana kedudukan pemilik rumah tersebut. Dalam penelitian ini, peneliti hanya akan membahas mengenai tipologi atap joglo, limasan, dan kampung.

\section{Metode Pelaksanaan}

Tahapan pelaksanaan adalah sebagai berikut :

a. Pengumpulan Data

Peneliti mengumpulkan data-data yang bersumber dari literatur maupun internet mengenai arsitektur Jawa, yang meliputi bentuk atap, pembagian ruang dalam, dan detail arsitektur Jawa.

b. Penarikan Kesimpulan

Berdasarkan data yang telah disusun, peneliti dapat menyimpulkan gambaran umum dan kesimpulan dari datadata yang ada.

\section{Hasil dan Pembahasan}

\subsection{Bentuk Atap Rumah Joglo}

Bentuk atap rumah joglo memiliki 3 tingkat yang dapat menunjukan strata sosial dari pemilik rumahnya, yang terdiri dari 2 golongan yaitu: golongan bangsawan, golongan menengah keatas (kaya). Rumah joglo memiliki bentuk atap yang beraneka ragam, hal itu dapat menggambarkan strata sosial dari pemilik. Joglo merupakan bangunan yang paling populer, bahkan masyarakat awam sering menganggap jenis rumah tradisional ini sebagai satu-satunya bentuk rumah tradisional masyarakat Jawa.

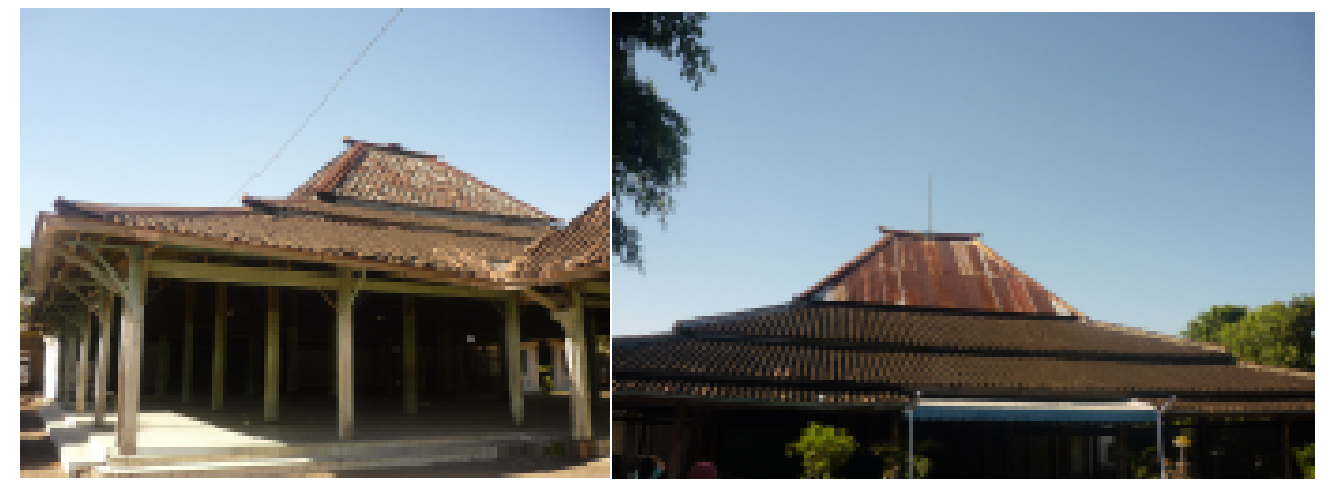

Gambar 1. Dalem Kepangeranan atau rumah bangsawan

Sumber : Roosandriantini, J. 2010

Orang awam berpendapat bahwa arsitektur Jawa yang identik dengan rumah joglo hanya dimiliki oleh kalangan bangsawan, dan strata sosial dan ekonomi menengah ke atas. Sebab dinilai bahwa bahan bangunan lebih banyak dan lahan lebih luas daripada jenis rumah jawa yang lain. Sehingga menjadi dasar muncul mitos dalam masyarakat bahwa rumah joglo tidak pantas untuk dimiliki oleh rakyat jelata, melainkan hanya dapat dimiliki orang terpandang atau terhormat.

Atap joglo memiliki beberapa ciri khas yang membedakannya dari rumah adat lainnya yaitu :

a. Menggunakan atap berbentuk trapesium (seakan-akan berbentuk piramida/atap limas)

b. Terdapat empat tiang utama yang mendukung atap di atasnya terdapat susunan khas berupa tiang-tiang berlapis yang diartikan sebagai tumpang sari.

c. Susunan ruang pada rumah bentuk joglo dapat dibedakan berdasarkan status pemilik rumah tersebut, yakni milik orang biasa dan milik orang bangsawan.

d. Susunan ruangan pada rumah bentuk joglo yang dimiliki oleh orang biasa dibagi menjadi tiga bagian, yaitu :

1. Ruang pertemuan (pendhopo).

2. Ruang tengah atau ruang untuk pentas wayang (pringgitan).

3. Ruang belakang (dalem) untuk ruang keluarga, yang terdiri dari 3 buah senthong (kamar) yaitu senthong kiri, tengah dan kanan. 


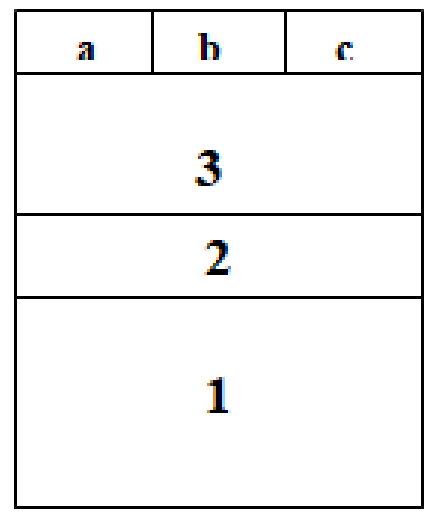

Gambar 2. Rumah bentuk joglo milik orang biasa (Sumber: Roosandriantini, 2010)

Keterangan gambar:
a. Senthong Kiwa
1. Pendopo
b. Senthong Tengen
2. Pringgitan
c. Senthong Kanan
3. Dalem

e. Susunan rumah joglo milik bangsawan (ningrat), mengalami perubahan penambahan pada ruangnya. Sebab aktivitas yang dilakukan oleh bangsawan/ raja sangatlah bervariasi sehingga penambahan ruang menyesuaikan dengan aktivitas. Pada rumah Joglo milik bangsawan sebelah kiri dan kanan dalem ada bangunan kecil yang memanjang dan biasa disebut gandhok yang terdiri dari kamar-kamar.

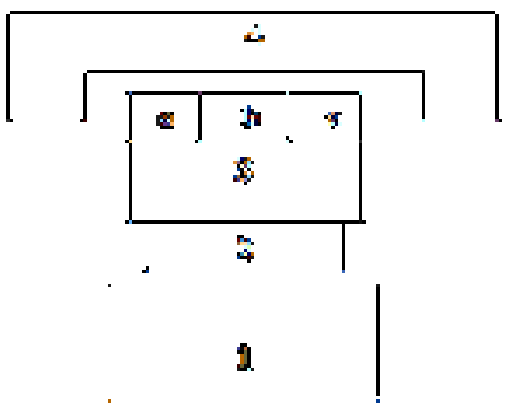

Gambar 3. Rumah bentuk joglo orang bangsawan Sumber: Roosandriantini, 2010

Keterangan gambar:
1. Pendopo
a. Senthong kiwa
2. Pringgitan
b. Senthong tengah
3. Dalem
c. Senthong tengen
4. Gandhok

f. Beberapa ruang di rumah Joglo memiliki kegunaan pada zaman dahulu, antara lain pendopo yang digunakan sebagai gudang ekonomi dan pabrik, pringgitan sebagai penghubung antara pendopo dan ndalem, dalem sebagai tempat penyimpan barang, senthowo kiwa/ kulon sebagai tempat tidur pangeran, senthong tengen sebagai tempat tidur keluarga pangeran.

g. Kegunaan rumah Joglo saat ini hampir semua ruang tidak ada kegunaan namun ada senthong kiwa/kulon digunakan sebagai tempat penyimpan barang, dan senthog tengen hanya berisi amben.

h. Penerapan tiang pada rumah Jawa, terdapat sistem pembagian kosmologis yang berpengaruh pada pembagian rumah, yaitu :
- Umpak
: sebagai bagian bawah
- Soko Guru
: sebagai bagian tengah
- Balok tumpang Sari
: sebagai bagian atas 


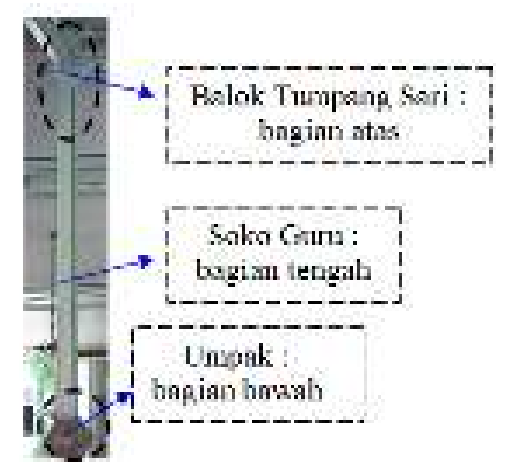

Gambar 4. Tiang Rumah Jawa

(Sumber: Roosandriantini, 2010)

i. Memiliki rumah induk terdiri dari beberapa bagian sebagai berikut :

\section{Pendapa/Pendopo}

Bagian ini terletak di depan rumah. Biasanya digunakan untuk aktivitas formal, seperti pertemuan, tempat pagelaran seni wayang kulit dan tari-tarian, serta upacara adat. Ruang ini menunjukkan sikap akrab dan terbuka, meskipun begitu pendopo seringkali dibuat megah dan berwibawa.

\section{Pringitan}

Bagian ini terletak antara pendapa dan rumah dalam (omah njero). Selain digunakan untuk jalan masuk, lorong juga kerap digunakan sebagai tempat pertunjukan wayang kulit. Bentuk dari pringitan seperti serambi berbentuk tiga persegi dan menghadap ke arah pendopo.

\section{Emperan}

Ini adalah penghubung antara pringitan dan umah njero. Bisa juga dikatakan sebagai teras depan karena lebarnya sekitar 2 meter. Emperan digunakan untuk menerima tamu, tempat bersantai, dan kegiatan publik lainnya. Pada emperan biasanya terdapat sepasang kursi kayu dan meja.

\section{Omah njero}

Bagian ini sering pula disebut omah mburi, dalem ageng, atau omah saja. Kadang disebut juga sebagai omahmburi, dalem ageng atau omah. Kata omah dalam masyarakat Jawa juga digunakan sebagai istilah yang mencakup arti kedomestikan, yaitu sebagai sebuah unit tempat tinggal.

\section{Senthong-kiwa}

Berada di sebelah kanan dan terdiri dari beberapa ruangan. Ada yang berfungsi sebagai kamar tidur, gudang, tempat menyimpaan persediaan makanan, dan lain sebagainya.

\section{Senthong tengah}

Bagian ini terletak ditengah bagian dalam. Sering juga disebut pedaringan, boma, atau krobongan. Sesuai dengan letaknya yang berada jauh di dalam rumah, bagian ini berfungsi sebagai tempat menyimpan benda-benda berharga, seperti harta keluarga atau pusaka semacam keris, dan lain sebagainya

\section{Senthong-tengen}

Bagian ini sama seperti senthong kiwa, baik fungsinya maupun pembagian ruangannya.

\section{Gandhok}

Merupakan bangunan tambahan yang letaknya mengitari sisi belakang dan samping bangunan inti.

\subsection{Bentuk Atap Rumah Limasan}

Kata "limasan" berasal dari kata limas. Rumah bentuk limasan mempunyai bentuk denah empat persegi panjang. Rumah bentuk limasan sederhana terdiri dari empat buah atap yaitu dua buah atap bernama kenjer atau cocor dan dua buah atap bernama brunjung berbentuk jajaran genjang sama kaki. Pada perkembangan selanjutnya, rumah bentuk limasan diberi penambahan pada sisi-sisinya yang disebut empyak emper atau atap emper dan kebanyakan menggunakan atap genteng tanah liat. 


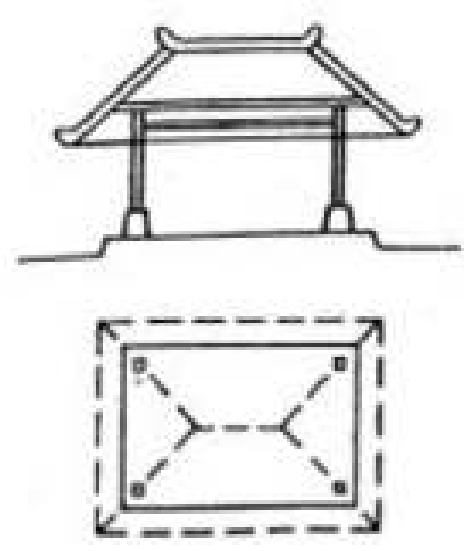

Gambar 5. Limasan Pokok

Sumber: Ismunandar, 1993

\subsection{Atap Rumah Bentuk Kampung}

Kata "kampung" dalam bahasa Jawa disamakan dengan kata "desa". Menurut keadaannya, rumah bentuk kampung sangat umum dipakai oleh orang desa (orang kebanyakan) dari pada orang ningrat atau orang yang lebih mampu. Ciri-ciri rumah kampung yaitu :

a. Menggunakan atap pelana yang berbentuk empat persegi panjang yang di lapisi dengan tutupan bernama tutup keyong. Yang paling sederhana biasanya memiliki 2 buah buah atap pelana yang menyamping pada bangunan.

b. Menggunakan denah yang berbetuk empat persegi panjang dan persegi.

c. Terdapat tiang-tiang penyangga setiap bangunan dengan jarak tertentu.

Pada jaman lampau, masyarakat berpandangan bahwa seseorang yang memiliki rumah bentuk kampung sebagai tempat tinggal berarti orang itu kurang mampu ekonominya.
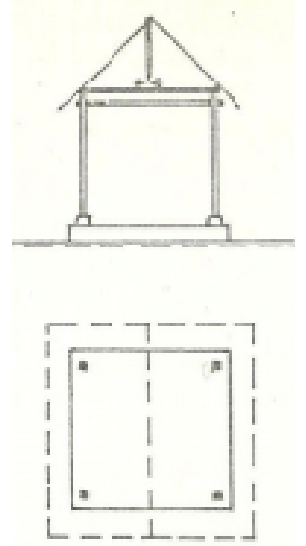

Gambar 6. Atap Kampung

Sumber: Ismunandar, 1993

\subsection{Hierarki Rumah Menurut Golongan Sosial}

Tipe bangunan rumah sangat bergantung pada aspek sosial, sehingga pemilik rumah dapat pengakuan dari masyarakat di sekitarnya. Berdasarkan tipe rumahnya, maka dapat dibedakan berdasarkan strata sosial dan perilaku pemilik rumah. Misalnya rumah tipe Joglo yang umumnya dimilik oleh kalangan menengah ke atas, baik golongan bangsawan atau priyayi. Hal ini dapat dipahami karena untuk membuat rumah bentuk Joglo sendiri dibutuhkan bahan bangunan yang lebih banyak dan lahan yang lebih luas dari jenis rumah lainnya. Strata pemilik rumah dapat diketahui dari bentuk atap dan perbedaan tinggi lantai yang digunakan pada rumah tersebut. 


\begin{tabular}{|c|c|c|c|c|}
\hline & Tipe Berak Arap & $\begin{array}{c}\text { Bagian } \\
\text { Bangsawan }\end{array}$ & $\begin{array}{c}\text { Bagan Deang } \\
\text { Kaya } \\
\text { (Pengusaha) }\end{array}$ & $\begin{array}{c}\text { Bagian Ralryat } \\
\text { Biasa }\end{array}$ \\
\hline \multirow[t]{3}{*}{ Bangaswan } & Joglo & & $\begin{array}{r}\text { Tamumdarean } \\
\text { atautcikoh } \\
\text { Masyarakat }\end{array}$ & $\begin{array}{l}\text { Pelayan atau } \\
\text { para pembanru } \\
\text { rumab tansza }\end{array}$ \\
\hline & $2 t$ & $\begin{array}{l}\text { Sebagian besar } \\
\text { para bungswan }\end{array}$ & $\begin{array}{l}\text { Sebagian lagi } \\
\text { crang kaya }\end{array}$ & $\begin{array}{l}\text { Sebagian kecd } \\
\text { rkyat biasa }\end{array}$ \\
\hline & Tipe Rentuk Atap & $\begin{array}{c}\text { Bagian } \\
\text { Bangawan }\end{array}$ & $\begin{array}{c}\text { Ragian Orang } \\
\text { Kaya } \\
\text { (Pengusaha) }\end{array}$ & $\begin{array}{c}\text { Bagan Rakyat } \\
\text { Biasa }\end{array}$ \\
\hline Menengah & Limasan & $\begin{array}{c}\text { Taruu } \\
\text { kehomatan dan } \\
\text { kasultanan atau } \\
\text { kasumanan } \\
\text { Separuh bagian } \\
\text { para bangsaman }\end{array}$ & $\begin{array}{c}\text { kehuarga } \\
\text { knubal } \\
\text { Sebagian besar } \\
\text { untuk orangkaya }\end{array}$ & $\begin{array}{c}\text { Pegawai, } \\
\text { pelayan atau } \\
\text { PRT } \\
\text { Separuh bagian } \\
\begin{array}{c}\text { laim rakyat } \\
\text { biasz }\end{array} \\
\end{array}$ \\
\hline Kampung & Kampung & $\begin{array}{c}\text { Tamm } \\
\text { kehomatan dan } \\
\text { utusan Sultan } \\
\text { atau Suran }\end{array}$ & $\begin{array}{c}\text { Tolkoh } \\
\text { nasyarakat dan } \\
\text { undangan dari }\end{array}$ & $\begin{array}{l}\text { Anggota } \\
\text { ketuager dan } \\
\text { kerabat sendin }\end{array}$ \\
\hline & & $\begin{array}{l}\text { Sebaginkecil } \\
\text { para bangsawan }\end{array}$ & $\begin{array}{l}\text { Sebagan lag } \\
\text { erang kaya }\end{array}$ & $\begin{array}{c}\text { Sebagan besar } \\
\text { takyat biasa. }\end{array}$ \\
\hline
\end{tabular}

Tabel 1. Hierarki Rumah Jawa menurut Golongan Sosial

(Sumber: Roosandriantini, 2010)

\section{Kesimpulan}

Berdasarkan data yang didapat, dan pada Tabel 1 dapat terlihat bahwa rumah tradisional Jawa memiliki bentuk atap yang dapat menandakan tingkat atau strata sosial dari pemilik rumah. Selain itu juga terdapat pembagian ruang berdasarkan fungsi dan sifatnya yaitu ruang publik yang bersifat umum hingga bersifat privat atau pribadi. Sehingga, rumah adat Jawa dapat menandakan hirarki sosial pemiliknya termasuk kalangan bangsawan, orang kaya/pengusaha atau rakyat biasa. Selain itu dengan pembagian ruang mulai pendopo - peringgitan - ndalem dapat dilihat sifat ruangnya. Pendopo sebagai ruang publik, peringgitan (ruang perantara) sebagai area semi publik sebab peralihan dari ruang publik menuju ruang privat. Sedangkan ndalem merupakan ruang privat yang terdiri dari senthong kiwo, tengen dan tengah. Hanya anggota keluarga saja yang diperbolehkan masuk.

\section{Ucapan Terima Kasih}

Terima kasih atas kerjasama dan semangat mahasiswa dalam usaha memunculkan minat dalam keinginan melakukan penelitian dan menulis karya ilmiah.

\section{Daftar Pustaka}

Cahyandari, Gerarda Orbita Ida.(2012).”Tata Ruang dan Elemen Arsitektur pada Rumah Jawa di Yogyakarta sebagai

Wujud Kategori Pola Aktivitas dalam Rumah Tangga”. Jurnal Arsitektur Komposisi, Volume 10, nomor 2.

Hamzuri.(1981). "Arsitektur Tradisional Jawa”. Depdikbud. Jakarta.

Ismunandar, K.R.(1986). Joglo,Arsitektur rumah tradisional Jawa. Semarang: Dahara Prize.

Ismunandar. (1993). Joglo: Arsitektur Rumah Tradisional Jawa. Semarang : Dhara Prize.

Mangunwijaya,Y. B.(1995). "Wastu Citra", PT Gramedia Pustaka Utama, Jakarta.

Pitana, T. (2007). "Reproduksi Simbolik Arsitektur Tradisional Jawa : Memahami Ruang Hidup Material Manusia Jawa". Gema Teknik, 2 (10), pp. 126 - 133.

Prijotomo, J.(1995). "Petungan Sistem Ukuran dalam Arsitektur Jawa”.Yogyakarta : Gajah Mada University Press. Roosandriantini, J.(2010).”'Identifikasi Konstribusi Perilaku Bermukim Bangsawan Jawa terhadap Wujud Fisik Arsitektur Pura Mangkunegaran Periode 1890-1930an”.[Thesis].Institut Teknologi Sepuluh Nopember.Surabaya. 


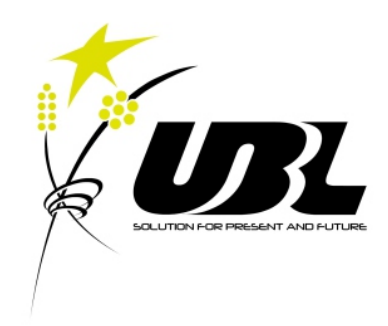

Published:

Program Studi Arsitektur Fakultas Teknik Universitas Bandar Lampung 